\title{
Győrffy Dóra
}

\section{Formalizálás helyett egymással versengő közelítések}

\author{
(Csaba László: Európai közgazdaságtan. \\ Akadémiai Kiadó, Budapest, 2014, 198 oldal, 3990 Ft)
}

\begin{abstract}
A közgazdaságtudomány megújulásának szükségessége a 2008-ban kitört globális válságot követően immár nem csupán a szakma egy szűk körének meggyőződése, hanem a tágabb közvélemény érdeklődésére is számot tartó kérdés. II. Erzsébet angol királynő 2008 novemberében a London School of Economics rendezvényén tette fel kérdését arról, miért nem látta előre senki, hogy egy ekkora válság van kibontakozóban. A kérdésre angol közgazdászok azt a választ fogalmazták meg, hogy a közgazdászok képzése és kultúrája a valós jelenségek vizsgálatával szemben elsősorban az axiomatikus matematikai modellezésre koncentrál, mely a tudományt az alkalmazott matematika egyik ágává tette (Hodgson és szerzőtársai 2009). A válság csillapodásával azonban a közgazdaságtudományról szóló vita is némileg háttérbe szorult. II. Erzsébet is megnyugodhatott, hiszen négy évvel az eredeti kérdés után az angol jegybankban tett látogatásakor elmagyarázták neki: a válságok ritkák és megjósolhatatlanok, a legutóbbit elsősorban a fellendülés miatti túlzott elbizakodottság okozta, ám mindent megtesznek a következő megakadályozásáért (Neate 2012). Akiket ez a válasz - a pénzügyi válságok irodalmának akárcsak felszínes ismerete alapján - nem teljesen nyugtat meg, annak tovább kell gondolkoznia a közgazdaságtudomány megújulásának lehetséges irányairól. Csaba László könyve elsősorban nekik szól.

Az Európai közgazdaságtan című mű kapcsán az első legfontosabb megállapítás az, hogy egy magyar nyelvű tudományos monográfiáról van szó. A szakmában egyre nagyobb teret nyer az a gondolat, miszerint a valódi tudományos teljesítményt elsősorban az angol nyelvü folyóiratcikkek tükrözik ${ }^{1}$. Ennek mélyebb oka: „a meghatározó vélemények szerint a világ annyira bonyolult, hogy ha egy jól kiragadott részletét sikerül megértenünk, az a legtöbb,
\end{abstract}

Győrffy Dóra (PhD) habilitált egyetemi docens a Pázmány Péter Katolikus Egyetem Bölcsészet-és Társadalomtudományi Karán.E-mail:gyorffy.dora@btk.ppke.hu.

\footnotetext{
${ }^{1}$ Lásd például a könyvben is gyakran idézett Benczúr és szerzőtársai (2013:727) gondolatmenetét arról, hogy a PhDdisszertáció legmegfelelöbb müfaja a "három, potenciálisan kapcsolódó esszé", melyek „elég rangos", lehetöleg nemzetközi folyóiratban jelennek meg. Indoklásuk szerint "mivel manapság a közgazdaságtanban a jellemző akadémiai termék a folyóiratcikk, és az egész nemzetközi kutatási intézményrendszer erre a termékre épül (általánosan elfogadott folyóiratrangsorokkal, bírálói rendszerrel, ezekre épülő elöléptetési gyakorlattal stb.), természetesnek tünik, hogy a diszszertáció is ezt a múfajt célozza meg."
} 
amit várhatunk... - és erre a cikk müfaja a legalkalmasabb" (Benczúr és szerzötársai 2013:727). Ezzel szemben a könyv, a Magyar Tudományos Akadémia kétszáz éve elindult küldetésének szellemében, magyarul született, és ebben Csaba László azt az álláspontot képviseli, hogy nem szabad elrettenni a tágabb kérdésektől. Ezen kérdések megvitatásának alapvető kifejezésformája a könyv - terjedelme lehetővé teszi a kontextus és a releváns szakirodalmi előzmények bemutatását, a saját kérdés feltevését és megválaszolását, majd az eredmények értékelését és az esetleges ellenérvek megvitatását.

Ebben a kötetben a tágabb téma a közgazdaságtudomány módszertana, és a fö cél egy olyan közgazdaságtani paradigma felvázolása, amely nyitott a valós élet jelenségeire, és a gyakorlati életben is alkalmazható tudást nyújt. Ennek jegyében a két bevezető rész után a kötet harmadik fejezete arra keresi a választ, hol tart ma a világ közgazdaság-tudománya és milyen lehet egy új, Európa-centrikus megközelítés.

A közgazdaság-tudomány állásával kapcsolatos legfontosabb megállapítás, hogy a szakmában egy sajátos kettősség jött létre - míg a tananyagok egyre inkább egyesülnek az amerikai neoklasszikus szintézis alapján, magában a tudományban „sajátos erjedési folyamat figyelhető meg", és a heterodox irányzatok képviselői egyre nagyobb teret kapnak a szakmában. Míg a vezető egyetemek és folyóiratok a korábbinál is kevésbé toleránsak az alternatív megközelítések irányában, az üzleti élet és a gazdaságpolitikai gyakorlat, illetve a tudomány közötti szakadék megnőtt, aminek következtében egyre többen kérdőjelezik meg a föáram relevanciáját.A fóáramot Csaba László a Paul Samuelson által kialakított módszertannal azonosítja, amely elsősorban deduktív, modellszerü gondolkodást és matematikai kifejtést követel meg. Fontos megállapítás: „hogyha a tárgyalásmód adott, akkor a kérdésfeltevés is adva lesz" (48. o.), azaz kimaradnak olyan kérdések, például a pénzügyi válságok vagy a későbbiekben tárgyalt rendszerváltás, amelyeket ebben a keretben csak nagyon korlátozottan lehet tárgyalni. A fóáram dominanciáját a szerző a tudomány és az oktatás - a piacméret és szervezettség okán bekövetkező - amerikanizálódásának tulajdonítja, amelynek mértéke más tudományszakokhoz viszonyítva példátlan. Következménye pedig a kérdések és a módszertan egységesülése, azaz a diverzitás csökkenése, amely - az élővilághoz hasonlóan - a tudomány esetében is magában hordozza a degeneráció veszélyét. Európában a szélesebb alapozás, a nagyobb kérdések művelése helyzeti előnynek tekinthetö, és ezek elhagyása az amerikai minta kedvéért azt jelenti, hogy a kontinens az „örök másodhegedűs” szerepét vállalja. Ezt jelzi például a német közgazdaság-tudomány alakulása, ahol kvázi kihalt az ordoliberális megközelítés, miközben az amerikai piacra a korábbi német lapok nem igazán tudtak betörni.

A fenti megfontolások alapján a szerző egy európai közgazdaságtani paradigma szükségességét fogalmazza meg. Ennek célja az európai elemzési hagyományok újraélesztése, a társadalom számára releváns gondoltok megfogalmazása és ellenőrzése, majd a gazdaság és társadalom befolyásolása nyílt vita keretében. Ebben a gondolkodási keretben a tárgy nem lehet azonos a módszerrel - tehát nem az a cél, hogy a módszert minél több lehetséges területre elterjesszük a gyerekvállalástól a dohányzásig, hanem az, hogy a nemzetek gazdaságát mint a közgazdaságtan tárgyát minél inkább megértsük. Ennek során nem megkerülhető a történeti és elméleti elözmények ismerete. A formalizálás pedig nem tekinthetö önértéknek, helyette Csaba László az egymással versengő közelítések párhuzamos alkalmazását javasolja.

A közgazdaság-tudomány normatív paradigmáját követően a könyv negyedik fejezete egy modellt vázol fel arról a kérdésről, milyen társadalomban szeretnénk élni - nem 
az önérdekét hajszoló homo oeconomicus, hanem a kapcsolataiban élő és kiteljesedö, valóságos ember. Ezt a modellt az európai szociális piacgazdaság elméletében találja meg. A modellnek mindhárom eleme lényeges: európai, szociális és piacgazdaság. Három olyan fogalom, amely napjainkban sokat veszít népszerüségéből.

A könyv egészén végighúzódik az elkötelezettség Európa mellett, amely ebben a fejezetben van leginkább kifejtve. A szerző elismeri, hogy az Európai Unió nem minden világok legjobbika, amint azt sokan remélték a rendszerváltozás hajnalán, de mindenképpen jobb benne lenni, mint kívüle. A fejezet egyik legizgalmasabb része, amikor felsorolja az alternatív lehetőségeket - Kína, Oroszország, Irán, Japán és az Egyesült Államok rendszere, mely más-más okok miatt lehet vonzó egyeseknek. Ám eltérő okokból egy emberközpontú társadalom képébe nehezen illenek bele. Míg a keleti rezsimek kapcsán ez viszonylag magától értetődő, az Egyesült Államokban a szerző a munka és a szabadidő egészségtelen arányára hívja fel a figyelmet.

A gondolatmenet második eleme a szociális jelző, amely ebben az esetben nem szocialistát, és még kevésbé valami egyenlősítő gondolatot takar. Kiindulópontként Wilhelm Röpke gondolataira támaszkodik, aki a nácizmus és a kommunizmus kérlelhetetlen ellenzőjeként egyaránt elutasította a parancsgazdaság és a zabolátlan piacgazdaság minden formáját, mert más-más módon materialistának és embertelennek látta ezeket. Alapproblémának tekintette a társadalom proletarizálódását, azaz a nincstelen, képzetlen, gyökértelen tömeg kialakulását. Ez a tömeg anyagi érdekein, nyers érzelmein és a látványokon, valamint a tömegrendezvényeken és tömegtájékoztatáson keresztül könnyen manipulálható.

Röpke számára ezért a társadalmi modell alapvető feladata a társadalom de-proletarizálása, vagyis az emberi léptékủ és természetủ életviszonyok kialakítása. Ez olyan gazdálkodási és települési viszonyok létrehozása lehet, ami képes meghaladni az indusztrializmus egyoldalúságait. Ezek teszik lehetővé a kisközösségek virágzását, ami azt jelenti, hogy az egyén nem marad elszigetelt a tömegben, hanem közösséget alkot. Ez többek között az állam túlterjeszkedésével szemben is védelmet biztosít.

A fejezetben külön rész szól arról, hogy mi különbözteti meg ezt a felfogást a jóléti államtól. Bár a valóságban sokszor nehéz a kettőt szétválasztani, a modellek szintjén ez a felfogás az egyéni felelősségvállalás elvére épít, nem kíván jövedelmi egyenlősítést, és a szociálpolitika célzott marad. Alapvetőnek tekinti a versenyt, a gazdasági tevékenységekben a koncentrálódás és az agglomeráció elleni fellépést, illetve a sokszínűség megőrzését a szolgáltatásokban - beleértve az egészségügyet és az oktatást.

A fentiekből természetesen következik az, hogy az emberséges társadalom modellje a piacgazdaság, mivel csak ez képes az egyéni autonómiát biztosítani és megőrizni. Ebben a modellben az állam szükségszerüen korlátozott, részben az intézményrendszer, részben pedig a kisközösségek ereje által. A fejezet több helyen is hangsúlyozza Walter Eucken gondolatait az állam szabályozó szerepéről, mely szemben állt mind a weimari, mind a náci korszak a „konkrét helyzet konkrét elemzése” alapján hozott gazdaságpolitikai rögtönzésével. A gazdaságot rendszerszemléletben értelmezve Eucken amellett érvelt, hogy mivel az állami beavatkozások hatása elöre megjósolhatatlan egy komplex rendszerben, a beavatkozásokkal csínján kell bánni. Az állam alapvető feladata a magántulajdon, jogállamiság, árstabilitás és verseny biztosítása és fenntartása, nem pedig a gazdaság mikromenedzselése.

Az ordoliberalizmus gondolatköre a háború utáni német csoda elméleti alapvetését adta. A fejezet hosszan elemzi azt a kérdést, mennyire működik ez még napjainkban. Bemutatja, hogyan korcsosodott a német szociális piacgazdaság jóléti állammá, és ez milyen követ- 
kezményekkel járt a növekedésre. Szintén bemutatja, miként szorult vissza az ordoliberális iskola a német gondolkodásban az amerikai föáram mögött. A leírtak ellenére azonban a 2000-es évek reformjai azt igazolták, hogy a modell képes a változásra és az alkalmazkodásra. Németország jelenlegi ereje ezt a képességet bizonyítja. Emellett a technológiai fejlödésben is olyan változások zajlottak le, amelyek lehetővé teszik azt a fajta emberi léptéket, amely a röpkei gondolat alapja. A technológiai fejlődés nem a nagyságrendi megtakarítások, hanem a szakosodás, a kis sorozatok, az egyedi igények - a 21. században a tömeges testreszabás - irányába mozdul. Ebből adódóan az európai szociális piacgazdaság összeegyeztethetö a technológiai fejlődéssel, a globalizáció jelentette versennyel, illetve azzal az emberképpel, amely túllép a homo oeconomicus jelentette kereten. Éppen ezért normatív értelemben modellnek tekinthetö.

A következő fejezet a rendszerváltás értékelésének módszertani kérdéseivel foglalkozik. Megállapítja, hogy ennek vizsgálatára különösen alkalmatlan a föáramú megközelítés, hiszen nem tömegjelenségről van szó, nem ismétlődik, nem általánosítható, nincs benne reprezentatív egyed, és nem írható le matematikai modellekkel. Eközben azonban az esemény egy sor olyan kérdést vetett fel, amelyeket nem lehet nem közgazdaságinak tekinteni - a jövedelemeloszlástól a növekedési ütemig.

A rendszerváltás vizsgálatában (is) elsődleges szerepet játszik az a kérdés, mit és hogyan mérünk. Ennek kapcsán a szerző abból a megfontolásból indul ki, hogy a közvéleményben uralkodó nézetté vált a rendszerváltás sikertelennek való megítélése, mely részben a szocialista rendszerrel való összehasonlításból, részben a konvergencia elmaradásából fakad. Ezekben a kérdésekben nagy szerepet játszanak a bruttó nemzeti jövedelem kimutatásának nehézségei, amelyek a szocialista rendszer kapcsán nem tartalmazták a mindenütt meglevő hiányjelenségeket, míg a rendszerváltási időszak után a minőség és a választék dimenzióit. Ez azt jelenti, hogy egy kétfelé torzító tükröt látunk, amely túlméri a szocializmus teljesítményét és alulméri az 1990-es évekét. Az érzékelt kudarc másik összetevője az elmaradt konvergencia a fejlett világhoz, amely fakadhat a gazdasági nacionalizmus vagy a neoklasszikus feltételes konvergencia gondolatmenetéből. A felzárkózás igénye azonban a szerző szerint egy teljesen irreális sikermérce, hiszen a történeti statisztikák alapján semmi nem utal arra, hogy ez egy szükségszerü, a belső feltételektől független folyamat lenne.

A rendszerváltás vizsgálatának egy másik fontos szempontja az, milyen a megfelelő elemzési keret olyan folyamatok elemzésére, ahol rendszeresen szembesülünk azzal, hogy a fóáram által javasolt racionális javaslatokat külső vagy véletlen tényezők általában felülírják. A szerző öt lehetséges iskolát mutat be: marxizmus, neoklasszikus föáram, klasszikus keynesianizmus, Washingtoni konszenzus, ordoliberalizmus. A marxizmus kapcsán megállapítja, hogy a rendszerváltás elemzésére lényegéből adódóan alkalmatlan, hisz az épp az általa elutasított rendszernek a kiépítéséről és bebetonozásáról szól. A fóáram kapcsán leszögezi, hogy mivel nincsenek benne intézmények, és a rendszerváltás éppen ezek megteremtéséről szól nem ismétlődő folyamatok során, ez a keret nem igazán lehetett releváns. Szintén nem lehet alkalmas elemzésre a keynesi paradigma, hiszen ez a kereslet, és nem a kínálat összeomlására vonatkozik, illetve szerkezeti, szabályozási gondok enyhítését nem lehet a pénzkínálat növelésétől várni - különösen jól működő pénzügyi közvetítőrendszer nélkül. Végül a szerző szintén elutasítja a washingtoni konszenzust, melyet nem a régióra találtak ki, és nem intézményépítésről, hanem a külső és belső fizetőképesség fenntartásáról szól. Az alternatívák kizárása után a szerző az előző fejezet szellemében az európai szociális piacgazdaság elméleti alapját jelentő ordoliberalizmus 
mellett érvel, amely kiemelt fontosságot tulajdonít az intézményeknek, különösen az erős, ám nem mikro-menedzseléssel foglalkozó államnak.

Az elméleti megfontolásokat követően Csaba László a rendszerváltás mérlegét vonja meg, a fejezet „Félig üres vagy félig tele van a pohár?” címének jegyében. A kedvező fejlemények között említi a nemzetközi kereskedelmi áramlásokba való bekapcsolódást, működő tőke beáramlását és ennek versenyképesség-javító hatását, az infokommunikációs eszközök elterjedését, a pénzügyi közvetítőrendszer megerősödését és a szolgáltató társadalom kialakulását. A kedvezőtlen fejlemények közé tartozik a munkapiaci részvétel alacsony szintje, a kiterjedt második gazdaság fennmaradása és az átláthatóság hiánya, amelyek mind hozzájárulnak a társadalmi elégedetlenséghez és az állammal való együttmüködés korlátozottságához.

A fejezet a jövőbeni növekedési lehetőségek felvázolásával egy nem túlzottan optimista jövőképet mutat be. Miután kifejti, hogy az EU semmiképpen sem tekinthető a világgazdaság növekedési gócpontjának, bemutatja: a rendszerváltó országok belső tényezői sem adnak okot túlzott bizakodásra. A tőkeképződés ugyan nem kirívóan alacsony szintü, de nem is délkelet-ázsiai léptékü, ezért beruházás-vezérelt növekedésre nem lehet számítani. A munkaerő kapcsán nem a mennyiség, hanem a minőség hiányzik - és szintén nem elhanyagolható, hogy a foglalkoztatás még a gyors növekedés éveiben is lassan nőtt a régió országaiban. Az innovációra sem igen lehet számítani, hisz a térség országai évtizedek óta alig költenek K+F-re. Mindezeket a folyamatokat súlyosbítja a bizalom alacsony szintje, amelyre pedig egyre növekvő mértékben lenne szükség, a megtakarításoktól a beruházásokig.A záró fejezetben a szerző visszatér az elmélethez, és arra a kérdésre keresi a választ, hogy mit adott a posztkommunista átmenet tanulmányozása a világ közgazdaság-tudományának. A fejezet első megállapítása, hogy a rendszerváltás során a módszertani individualizmus - azaz a makrogazdasági folyamatok visszavezetése mikroökonómiai alapokra - tévútnak bizonyult. Az egyéni döntésekből egyszerüen nem lehet levezetni a makrogazdasági folyamatokat. Ezt jól lehetett érzékelni az úgynevezett SLIP feladategyüttes ${ }^{2}$ kapcsán. A stabilizáció a transzformációs recesszióból való kilábalásban mindenütt perdöntő volt - annak ellenére, hogy a gazdaság számos szereplőjének, például az államnak, felettébb kedvezőtlen volt. Ugyanez igaz a piaci liberalizálásra, az intézményépítésre és a privatizációra. Ez a program sokkal inkább tárgyalható az ordoliberalizmus keretében, amely nem az individuális szereplökre, hanem a rendszer egészére koncentrál.

A rendszerváltás szintén rámutatott a módszertani pluralizmus szükségességére, hisz a legfontosabb kérdései egyszerüen nem érthetőek a neoklasszikus keretben. Ehelyett megkerülhetetlennek bizonyul(t) az empirikus, történeti, intézményi megközelítés, amely az összehasonlító és a politikai gazdaságtan módszereinek alkalmazását igényli. El kell vetni a fóáramot jellemző redukcionizmust is, és el kell fogadni a makro-megközelítés elsődlegességét, a rendszer komplexitását és ebből eredő bizonytalanságát - akár a pontos leírás és előrejelezhetőség kárára is. Szintén elvetendőek a valóságidegen feltevések, mint például a homo oeconomicus, és helyettük a társtudományok eredményeire való odafigyelés szükséges. A siker mércéje pedig a fenntarthatóság, amelynek egyaránt része a kormányzati kapacitás, a demográfiai folyamatok, a pénzügyi, környezeti, társadalmi és politikai fenntarthatóság.

2 SLIP: mozaikszó, amely a stabilizáció, liberalizáció, intézményépítés és privatizáció feladatait összegzi. 
A szerző azzal zárja a könyvét, hogy a gazdaságot egy komplex rendszernek kell felfogni, ahol indokolt az óvatosság mindenfajta forradalmi beavatkozással szemben, hisz a megfontolatlan beavatkozásnak a mellékhatásai súlyosabbak lehetnek a szándékoltnál. Éppen ezért nem célszerü például a pénzügyi mutatókat rögtönzött intézkedésekkel javítani, amelyek csorbítják az átláthatóságot és vélhetően a jogállamiságot is. A föáram eszköztára abban segíthet, hogy a rendszerbe való beavatkozások kockázatait előre felmérje. Csaba László a rendszerváltás vizsgálata kapcsán már hosszú ideje fogalmaz meg kritikát a közgazdaság-tudományi foáram gondolkodásmódjával szemben. A több mint két évtizednyi gondolkodás a módszertan kérdésein egy rendkívül határozott álláspontban fogalmazódik meg. A könyv ráadásul komoly normatív alapokra épül, amelyekből kiemelendő a közjó létébe és szolgálatának kötelezettségébe vetett hit, és az atomizált, önérdek-követő egyén, a homo oeconomicus emberképének elutasítása. A mondandó melletti tapasztalati és értékrendi elköteleződés egy módszertani könyvtől szokatlan, szenvedélyes, néhol egészen személyes hangvételben jelenik meg. Mindez rendkívül lendületes és kifejezetten olvasmányos szöveget eredményez.

A fóárammal szembeni szenvedélyes fellépés nyilvánvalóan sokakban kérdéseket ébreszt például a minőség megítélésével kapcsolatosan. Ha nem fogadjuk el a tudomány külső mércéit, hogyan mérjük a sikert? Hasonló kérdések merülnek fel az egyének karrierstratégiáival kapcsolatosan is, akik a kutatási téma és módszertan kiválasztása révén határozzák meg saját pályájukat - ebben az esetben nem kérdéses az egyéni és kollektív racionalitás a könyvben is alaposan kifejtett konfliktusa.

A felmerülő vitakérdések szinte vég nélkül folytathatóak. És éppen ezek miatt izgalmas ez a könyv - elgondolkodtat, provokál, vitára késztet a közgazdaság-tudományról és néhol saját magunkról is. A gondolatok túlmutatnak egy szűk szakterületen, ezért közgazdász és a társadalom kérdései iránt érdeklődő nem közgazdász kutatók egyaránt sokat tanulhatnak belőle.

\section{Hivatkozások}

Benczúr Péter - Kézdi Gábor - Kondor Péter - Mátyás László - Valentinyi Ákos (2013): Javaslat a magyarországi közgazdasági doktori képzés korszerüsitésére. Közgazdasági Szemle, Vol. 60, No 6:722732.Hodgson, G. M. - Dow, S. C. - Earl, P. E. - Foster, J. - Harcourt, G. C. - Metcalfe, J. S. - Ormerod, P. - Rosewell, B. - Sawyer, M. C. - Tylecote, A. (2009): Letter to the Queen. www.feed-charity.org/user/ image/queen2009b.pdf, Letöltve: 2014. 05. 17.

Neate, R. (2012): Queen finally finds out why no one saw the financial crisis coming. The Guardian, december 13. http://www.theguardian.com/uk/2012/dec/13/queen-financial-crisis-question, Letöltve: 2014. 05. 17. 